\title{
TNF-alpha antagonists for treatment of juvenile ankylosing spondylitis
}

\author{
I Orbán ${ }^{1 *}$, K Sevcic $^{2}$, EV Kiss ${ }^{3}$ \\ From 18th Pediatric Rheumatology European Society (PReS) Congress \\ Bruges, Belgium. 14-18 September 2011
}

\section{Background}

Juvenile onset sondylarthropathy is a term that refers to a group of human leucocyte antigen (HLA) -B27 associated inflammatory disorders affecting children under the age of 16 years.

The increased expression of tumor necrosis factor alpha (TNF-alpha) in synovial tissue of patients with juvenile onset and adults with active ankylosing spondylitis suggests a significant pathogenic role of TNF-alpha.

\section{Objective}

The authors present in an open label-pilot study the efficacy and safety of TNF-alpha antagonists (etanercept, adalimumab, infliximab) in 9 subjects with juvenile onset spondylarthropathy.

\section{Methods}

Patients with Juvenile ankylosing spondylitis (JAS) treated with TNF-alpha blockers after failing NSAIDs and DMARDs were evaluated in an open observational study (2005-2011). At baseline patients and disease characteristics were registered. Disease activity was evaluated before the start of the treatment then after 3, 12, 24, 36, 48, 60 months by the application of Visual analogue scale (VAS) for pain, Bath AS Disease Activity Index (BASDAI), Erythrocite sedimentation rate (ESR) and the functional ability by Bath AS Functional Index (BASFI). Adverse events were documented.

\section{Results}

From 9 patients, (2-with adalimumab, 2- with infliximab, 5 -with etanercept treatment), 5 were HLA- B27 positive, mean age: 28 (21-40) years, one girl, mean age at onset of

\footnotetext{
* Correspondence: orbanilon@freemail.hu

${ }^{1}$ Paediatric Rheumatologic Center of the National Institute of Rheumatology and Physiotherapy Budapest, Hungary

Full list of author information is available at the end of the article
}

disease: $12(8-17)$ years, mean age at the diagnosis: 20 (18-26) years. All disease activity parameters improved significantly in the first 3 months of treatments and respectively with years. After 5 years 6 patients continued the therapy. One side effect was observed.

\section{Conclusions}

Anti TNF alpha therapy is effective and well tolerated in patients with JAS.

\section{Author details}

${ }^{1}$ Paediatric Rheumatologic Center of the National Institute of Rheumatology and Physiotherapy Budapest, Hungary. ${ }^{2}$ Paediatric Rheumatologic Center of the National Institute of Rheumatology and Physiotherapy Budapest, Hungary. ${ }^{3}$ Paediatric Rheumatologic Center of the National Institute of Rheumatology and Physiotherapy Budapest, Hungary.

Published: 14 September 2011

doi:10.1186/1546-0096-9-S1-P270

Cite this article as: Orbán et al:: TNF-alpha antagonists for treatment of juvenile ankylosing spondylitis. Pediatric Rheumatology 2011 9(Suppl 1): P270.

Submit your next manuscript to BioMed Central and take full advantage of:

- Convenient online submission

- Thorough peer review

- No space constraints or color figure charges

- Immediate publication on acceptance

- Inclusion in PubMed, CAS, Scopus and Google Scholar

- Research which is freely available for redistribution 